\title{
EFEK EKSTRAK METANOL DAUN SALAM (SYZYGIUM POLYANTHUM) TERHADAP PERUBAHAN UKURAM BATU GINJAL
}

\author{
Laila Rahmah*, Muhammad Amir Masruhim, Riski Sulistiarini \\ ${ }^{11}$ Laboratorium Penelitian dan Pengembangan FARMAKA TROPIS Fakultas Farmasi \\ Universitas Mulawarman, Samarinda, Kalimantan Timur \\ ${ }^{2}$ Laboratorium Kimia Analisis Politeknik Negeri Samarinda, Kalimantan Timur \\ *Email: lailarahmah66@gmail.com
}

\begin{abstract}
ABSTRAK
Daun salam (Syzygium polyanthum) banyak digunakan masyarakat sebagai penambah aroma masakan. Secara empirik daun salam biasanya digunakan masyarakat sebagai ramuan untuk mengobati ginjal. Tujuan penelitian ini adalah untuk mengetahui efek ekstrak metanol daun salam (Syzygium polyanthum) terhadap perubahan ukuran batu ginjal. Ekstrak daun salam (Syzygium polyanthum) dibuat secara maserasi menggunakan pelarut metanol. Pengujian ini dilakukan dengan metode antikalkuli untuk mengetahui perubahan kadar kalsium oksalat ginjal setelah diinduksi etilen glikol $0,75 \%$ dan ammonium klorida $2 \%$ yang dicampurkan ke dalam air minum. Hasil pengujian menunjukkan bahwa esktrak metanol daun Salam (Syzygium polyanthum) memberikan efek terhadap perubahan ukuran batu ginjal.
\end{abstract}

Kata Kunci : Syzygium polyanthum, batu ginjal, kalsium oksalat

\begin{abstract}
Bay leaf (Syzygium polyanthum) is used as an additive aroma of food. Empirically the leaves are commonly used as an herb to treat people the kidney complaint. The purpose of this study was to determine the effect of the methanol extract of leaves (Syzygium polyanthum) to change the size of kidney stones. Bay leaf extract (Syzygium polyanthum) was prepared by maceration using methanol. This testing is done with antikalkuli method to determine changes in the levels of calcium oxalate kidney's rats after induction of ethylene glycol and ammonium chloride $0.75 \% 2 \%$ were mixed into drinking water. The test results showed that the methanol extract of leaves (Syzygium polyanthum) give effect to changes in the size of kidney stones.
\end{abstract}

Keywords: Syzygium polyanthum, kidney stones, calcium oxalate

\section{PENDAHULUAN}

Indonesia merupakan Negara berkembang berbentuk kepulauan yang kaya beragam jenis flora bermanfaat, baik tanaman obat maupun tanaman non obat. Indonesia memiliki predikat sebagai Negara terbesar kedua di dunia yang kaya akan bahan alam hayati baik dari spesies tanaman endemik maupun beragam jenis tanaman obatnya. Setiap pulau di Indonesia memiliki jenis tanaman khas yang dapat tumbuh sesuai dengan iklim maupun kondisi tanah nya. Ribuan tanaman obat telah banyak tumbuh di setiap daerah di 
Indonesia, baik yang jumlahnya sedikit hingga tanaman obat yang belum banyak diketahui manfaatnya untuk mengobati penyakit.

Penyakit batu ginjal merupakan penyakit saluran kemih yang banyak menyerang orang dewasa. Adanya batu ginjal di dalam tubuh dapat mengakibatkan nyeri pada saluran kemih, gagal ginjal, hingga kematian. Angka kejadian penderita penyakit batu ginjal setiap tahunnya mengalami peningkatan signifikan terutama di Negara berkembang termasuk Indonesia. Secara medis, untuk membuang batu ginjal dari dalam tubuh adalah melalui operasi yang memerlukan biaya besar. Namun sebenarnya pemanfaatan tanaman juga merupakan salah satu metode terapi yang banyak digunakan masyarakat saat ini.

Kalimantan timur merupakan salah satu provinsi di Indonesia yang mempunyai hutan tropis dan banyak jenis tanaman. Jumlah spesies tanaman di hutan tropis Indonesia termasuk Kalimantan Timur adalah sekitar 1.300 jenis tumbuhan berkhasiat obat. Salah satu tanaman yang banyak digunakan masyarakat kabupaten Muaraan Calong Kutai Timur Kalimantan Timur untuk mengobat penyakit adalah daun salam (Syzygium polyanthum). Biasanya daun salam (Syzygium polyanthum) digunakan sebagai penambah aroma makanan. Namun, masyarakat Muaraan Calong tidak hanya menggunkan daun salam sebagai penambah aroma makanan tetapi juga secara empiris digunakan untuk mengobati penyakit ginjal.

Daun salam (Syzygium polyanthum) adalah tanaman yang dapat tumbuh dengan baik di Indonesia. Herliana (2013) melaporkan bahwa tanaman ini mengandung banyak minyak atisiri, tanin, dan flavonoid. Har et al, 2012 melaporkan bahwa ekstrak metanol daun salam (Syzygium polyanthum) menunjukkan aktivitas antioksidan pada $\mathrm{IC}_{50}$ dengan nilai 90,85 $\mu \mathrm{g} / \mathrm{ml}$ dibandingkan dengan standar quersetin. Daun salam juga memiliki aktivitas antiinflamasi, antioksidan, antibakteri, dan antijamur (Malik dan Aktsar, 2013).

Penelitian ini dilakukan untuk mengetahui efek ekstrak metanol daun salam (Syzygium polyanthum) terhadap perubahan ukuran batu ginjal. Tujuan dilakukannya penelitian ini adalah untuk mengetahui efek ekstrak methanol daun salam (Syzygium polyanthum) terhadap perubahan ukuran batu ginjal dilihat dari perubahan kadar kalsium oksalat ginjal.

\section{METODE PENELITIAN}

\section{Bahan}

Daun Salam, metanol, asam nitrat pekat, ammonium klorida, etilen glikol, kloroform, aqua destilata, Natrium klorida 0,9\%

\section{Peralatan}

Toples kaca, rotary evaporator, Spektrofotometer Serapan Atom, pemanas listrik, oven, alat bedah, sonde tikus, water bath, timbangan analitik, labu ukur, gelas kimia, cawan porselen, pipet ukur, penyaring buncher

\section{Prosedur}

\section{Pembuatan simplisia}

Daun Salam segar yang dipetik pada pagi hari dikumpulkan kemudian ditimbang, dicuci dengan air mengalir, lalu dikering anginkan, ditimbang daun salam kering, disortasi kering, disimpan. 


\section{Ekstraksi}

Simplisia yang telah jadi kemudian dipotong menjadi ukuran kecil-kecil kemudian dimasukan ke dalam toples kaca, direndam dengan methanol teknis sebanyak 2,5 liter, diaduk, kemudian didiamkan selama 7 hari sambil setiap hari diaduk, disaring, kemudian diuapkan di rotary evaporator hingga terbentuk ekstrak kental, kemudian dikeringkan di atas water bath.

\section{Pengujian}

Pengujian dilakukan dengan cara mengadaptasikan hewan uji selama 10 hari, kemudian dikelompokkan tikus menjadi 3 kelompok yaitu kelompok kontrol negatif, kontrol normal, dan uji dosis $250 \mathrm{mg} / \mathrm{Kg}$ BB. Semua hewan uji kecuali kontrol normal diinduksikan dengan air minum yang mengandung etilen glikol $0,75 \%$ dan $2 \%$ selama 14 hari ad libitum, dan dicatat bobot badan tikus setiap harinya. Pada kontrol normal diberikan pakan dan air minum biasa. Kemudian diinduksikan ekstrak daun salam dengan dosis $250 \mathrm{mg} / \mathrm{Kg}$ BB kepada kelompok uji selama 7 hari. Pada hari ke-8 semua hewan uji dieutanasia kemudian diambil organ ginjal, dikarakterisasi berdasarkan bobot, warna, dan ukuran.

\section{Preparasi sampel}

Ginjal kanan dikeringkan di dalam oven hingga perlahan hingga suhu $100{ }^{\circ} \mathrm{C}$ kemudian dihitung bobot ginjal kering, diiris kecil-kecil, diambil $100 \mathrm{mg}$ sampel kemudian ditambahkan asam nitrat $0,5 \mathrm{~N}$ ke dalam sampel ginjal kering tersebut, dipanaskan hingga larutan berubah warna kekuningan.

\section{Pengukuran kadar kalsium oksalat}

Larutan hasil pelarutan ginjal dimasukkan ke dalam labu ukur 100 ml kemudian ditambahkan aqua destilata hingga volume $100 \mathrm{ml}$. kemudian dianalisis kadar kalsium oksalat menggunakan Spektrofotometer Serapan Atom.

\section{HASIL DAN PEMBAHASAN}

Berikut ini adalah tabel hasil kadar kalsium oksalat ginjal pada kelompok tikus normal yang tidak diinduksi dengan inducer dan yang diinduksi inducer air minum yang mengandung etlen glikol 0,75\% dan ammonium klorida $2 \%$.

Tabel 1. Tabel Kadar Kalsium Oksalat Kelompok kontrol normal dan kelompok induksi

\begin{tabular}{lc}
\multicolumn{1}{c}{ Kelompok } & Kadar kalsium oksalat (\%) \\
\hline Kontrol normal & 0.36 \\
Kelompok induksi Replikasi-1 & 1.24 \\
Kelompok induksi Replikasi-2 & 0.56 \\
Kelompok induksi Replikasi-3 & 0.64 \\
Kelompok induksi Rata-rata & 0.45 \\
\hline
\end{tabular}

Berdasarkan tabel diatas, dapat dilihat bahwa kadar kalsium oksalat ginjal tikus pada kelompok induksi yang diberikan induksi air minum yang mengandung etilen glikol $0,75 \%$ dan $2 \%$ ammonium klorida selama 14 hari mengalami peningkatan rata-rata 0.45 $\%$ dibandingkan dengan kelompok normal yang tidak diinduksi dengan air minum yang mengandung etilen glikol $0,75 \%$ dan $2 \%$ ammonium klorida, dapat disimpulkan bahwa proses penginduksian berhasil. 
Berikut ini adalah tabel hasil kadar kalsium oksalat ginjal pada kelompok tikus yang diinduksi ekstrak dosis $250 \mathrm{mg} / \mathrm{Kg} \mathrm{BB}$.

Tabel 2. Tabel Kadar Kalsium Oksalat Kelompok uji dosis $250 \mathrm{mg} / \mathrm{Kg}$ BB

\begin{tabular}{lc}
\hline \multicolumn{1}{c}{ Kelompok dosis $250 \mathrm{mg} / \mathrm{Kg} \mathrm{BB}$} & Kadar kalsium oksalat (\%) \\
\hline Replikasi-1 & 0.21 \\
Replikasi-2 & 0.16 \\
Replikasi-3 & 0.24 \\
\hline Rata-rata & 0.20 \\
\hline
\end{tabular}

Berdasarkan tabel diatas menunjukkan bahwa kelompok tikus uji yang diinduksikan ekstrak daun salam dengan dosis $250 \mathrm{mg} / \mathrm{Kg}$ BB selama 7 hari menurunkan kadar kalsium oksalat dengan rata-rata kadar kalsium oksalat sebesar $0.20 \%$.

Berikut ini adalah grafik batang perubahan kadar kalsium oksalat ginjal pada kelompok kontrol normal, induksi, dan dosis $250 \mathrm{mg} / \mathrm{Kg} \mathrm{BB}$

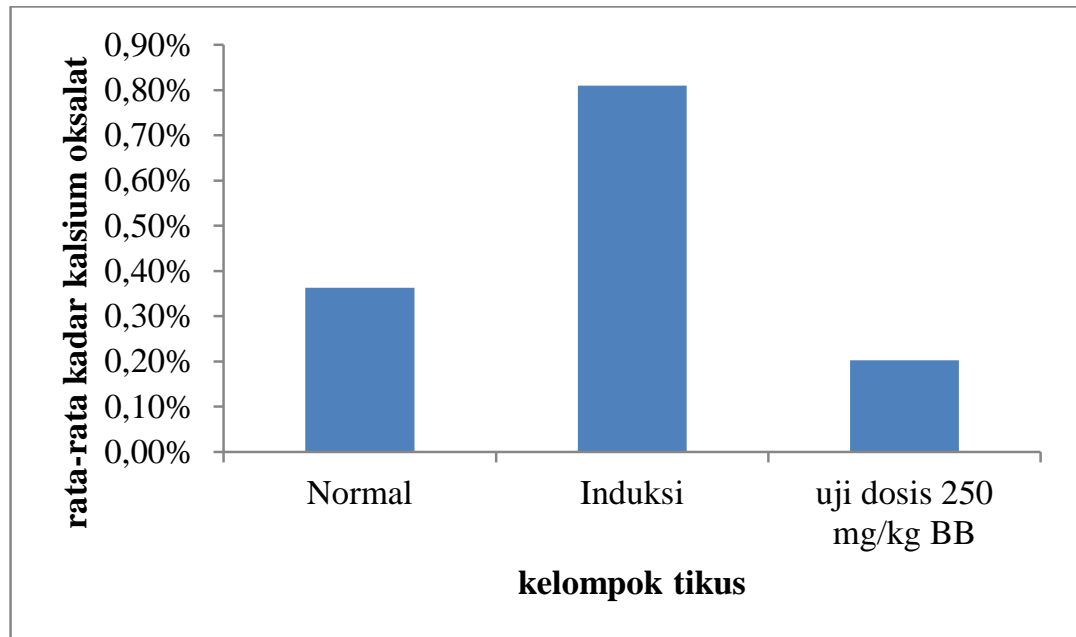

Grafik 1. Diagram Batang Kadar Kalsium Oksalat Ginjal Tikus Normal, Induksi， dan Uji Dosis $250 \mathrm{mg} / \mathrm{Kg} \mathrm{BB}$

Induksi batu ginjal dilakukan dengan cara menginduksi tikus dengan air minum yang mengandung etilen glikol $0,75 \%$ dan ammonium klorida $2 \%$ selama 14 hari ad alibitum. Dari Grafik 1. Menunjukkan bahwa terjadi peningkatan kadar kalsium oksalat pada kelompok tikus kontrol negatif sebesar 0,80\% yang diinduksi dengan air minum yang mengandung etilen glikol $0,75 \%$ dan ammonium klorida $2 \%$ dibandingkan dengan kelompok kontrol normal 0,36 \%. Kadar kalsium oksalat ginjal tikus kelompok uji setelah induksi ekstrak dosis $250 \mathrm{mg} / \mathrm{Kg}$ BB selama 7 hari sebesar 0,2 \% lebih rendah dibandingkan kadar kalsium oksalat kelompok negatif dan normal. Kandungan senyawa aktif flavonoid yang terdapat di dalam daun salam diduga berpotensi sebagai peluruh kristal kalsium oksalat pada batu ginjal melalui mekanisme diuretik. Hal ini menunjukkan bahwa ekstrak daun salam memiliki kemampuan dalam merubah ukuran batu ginjal dilihat 
dari adanya penurunan kadar kalsium oksalat ginjal kelompok uji dosis $250 \mathrm{mg} / \mathrm{Kg} \mathrm{BB}$ terhadap kelompok kontrol negatif dan kelompok normal.

\section{KESIMPULAN}

Ekstrak metanol daun salam (Syzygium polyanthum) dosis $250 \mathrm{mg} / \mathrm{Kg}$ BB memberikan efek perubahan ukuran batu ginjal dibuktikan dengan adanya penurunan kadar kalsium oksalat dibandingkan dengan kontrol negatif. Sebaiknya dilakukan variasi dosis ekstrak yang dapat memberikan efek perubahan batu ginjal

\section{DAFTAR PUSTAKA}

1. Har, Lee Wei dan Intan Safinar Ismail. 2012. Antioxidant activity, total phenolics and total flavonoids of Syzygium polyanthum (Wight) Walp leaves. International Journal Medika Arom Plants Vol. 2 No. 2

2. Herliana, Ersi. 2013. Diabetes Kandas Berkat Herbal. FMedia. Jakarta

3. Malik, Abdul dan Aktsar Roskiana Ahmad. 2013. Antidiarrhelal Activity of Ethanolic Extract of Bay Leaves (Syzigium plyanthum [Weught.]Walp). International Research Journal of Pharmacy Volume 4 No. 4 